\title{
Poesia em viagem ${ }^{1}$
}

\author{
Carlos ÁVILA
}

Lançado no ano passado, pela Editora da Universidade Federal do Pará - EDUFPA, "Ainda: em viagem" - último livro do poeta paraense Age de Carvalho, que vive há anos na Europa (desde 1986, entre Viena e Munique) - passou quase despercebido entre nós. Pouco ou nenhum retorno crítico recebeu.

Talvez o fato de viver no exterior e de não participar de forma presencial e mais ativa do cenário poético brasileiro, tenha deixado Age um tanto esquecido por aqui (o que ocorreu também, anteriormente, com o grande Murilo Mendes, radicado em Roma). Suas incursões pelo país têm sido rápidas e pontuais, em geral limitando-se ao Rio e a Belém, sua cidade natal; ele vive numa espécie de "duplo exílio - geográfico e poético", como bem observou o crítico Manuel da Costa Pinto.

Nascido em 58, Age vem construindo com persistência e constância uma obra muito peculiar, um pouco à margem das tendências mais marcantes da atual poesia brasileira (que contempla, na sua diversidade, desde a incisiva e agressiva verbalização sobre nosso "estado crítico", na poesia urbana de um Régis Bonvicino, até a dissolução de referentes e a abstração semântica de um Júlio Castañon Guimarães - isso para ficar apenas em dois nomes expressivos).

Já são oito ou nove títulos publicados por Age; “Ainda: em viagem”, livro dividido em seis seções, reafirma (e acentua) seu processo poético fragmentário e algo velado radicalizado em construção concisa; há uma trava sintático/semântica na sua poesia que remete a Paul Celan e a João Cabral (seguramente referenciais na poesia do paraense, entre outras "fontes"). Trata-se de uma poesia de fruição exigente, que não se entrega à primeira leitura.

Há ainda nesses poemas o corte abrupto de linhas (que não chegam a constituir versos no sentido convencional) e palavras; descontinuidades e interpolações - atritos da matéria verbal resultando em uma sonoridade atonal: "errando, errando -/Apátria, Exlândia, Des/terra, há anos: esse Estado/teu estado, de estar/em-viagem”.

Sob o signo do estranhamento, essa poesia inclui citações e evocações-hommages (como a tocante sequência de poemas sobre o amigo desaparecido, o também poeta Max Martins - na sexta e última seção do livro; verso-conversa entre o vivo e o morto: "uma

\footnotetext{
${ }^{1}$ Este texto é uma resenha crítica publicada pelo poeta e jornalista mineiro, Carlos Ávila, também amigo de Age de Carvalho, em seu blog Dom total, no dia 20 de janeiro de 2016.
} 
segunda vida,/a segunda vinda,/outra vez perdida a floração/do Arvoredo/este ano, outro ano/sem o Amigo").

Numa visada rápida, assim se articula a poética de Age de Carvalho - nome representativo no cenário atual; poesia “em viagem" - linguagem em tensão e trânsito contínuo, ainda a demandar maior (e mais profunda) leitura e atenção por parte da crítica; abaixo, uma das peças desse seu novo e instigante livro.

$* * * * *$

\author{
EU, INTIMO-ME \\ a reconhecer \\ (em ti, contigo \\ em viagem - nós, \\ dois faróis na estrada \\ farejando a escuridão luxuosa, \\ abolido tempoespaço \\ à visão da grande nebulosa: \\ tu, era eu-todo-estrelado, \\ o céu, espelho) \\ -me em \\ mim-mesmo.
}

